Reporting Date: December 1975 Issued: January 1976

\title{
The Zuni Mountains, New Mexico, As a Potential Dry Hot Rock Geothermal Energy Site
}

by

A. William Laughlin

Francis G. West 


\section{DISCLAIMER}

This report was prepared as an account of work sponsored by an agency of the United States Government. Neither the United States Government nor any agency Thereof, nor any of their employees, makes any warranty, express or implied, or assumes any legal liability or responsibility for the accuracy, completeness, or usefulness of any information, apparatus, product, or process disclosed, or represents that its use would not infringe privately owned rights. Reference herein to any specific commercial product, process, or service by trade name, trademark, manufacturer, or otherwise does not necessarily constitute or imply its endorsement, recommendation, or favoring by the United States Government or any agency thereof. The views and opinions of authors expressed herein do not necessarily state or reflect those of the United States Government or any agency thereof. 


\section{DISCLAIMER}

Portions of this document may be illegible in electronic image products. Images are produced from the best available original document. 
In the interest of prompt distribution, this report was not edited by the Technical Information staff.

Printed in the United States of America. Available from National Technical Information Service

U S Department of Commerce

5285 Port Royal hoad

Springfield, VA 22151

Price: Printed Copy $\$ 4.50$ Microfiche $\$ 2.25$

This report was prepared as an account of work sponsored
by the United States Government. Neither the United StateB by the United States Government. Neither the United States
nor the United States Energy Research and Development Adnor the United States Energy Research and Development Ad-
ministration, nor any of their employees, nor any of their contractors, subcontractors, or their employees, makes any
warranty, express or implied, or assumes any legal liability or responsibility for the accuracy. completeness, or usefulness of any information, apparatus, product, or process disclosed, or

represents that its use would not infringe privately owned 
THE ZUNI MOUNTAINS, NEW MEXICO, AS A POTENTIAL DRY HOT ROCK

GEOTHERMAL ENERGY SITE

by

A. William Laughlin and Francis G. West

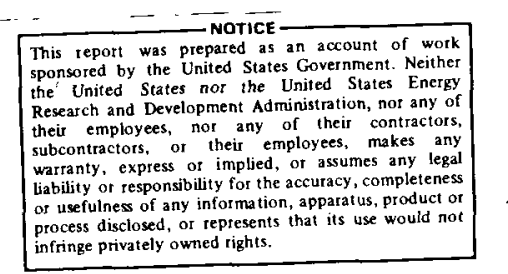

ABSTRACT

Many of the criteria for the successful exploitation of energy from dry hot rock are met in the Zuni Mountains, New Mexico. This area falls within a broad region of abnormally high heat flow on the Colorado Plateau. Within this region, a variety of evidence indicates that local "hot spots" may be present. These "hot spots" are prime targets for dry hot rock exploration. A site-evaluation program utilizing geological, geochemicalgeochronological, and geophysical techniques is proposed to delineate the optimal sites for subsequent exploratory drilling.

\section{INTRODUCTION}

The continuing success at the Los Alamos Scientific Laboratory's (LASL) first dry hot rock site in the Jemez Mountains, New Mexico, makes it appropriate to evaluate other possible sites for the extraction of geothermal energy by this method. Several areas in the western United States are presently under consideration as possible sites for future exploratory drilling. One of the most promising of these is the Zuni Mountains area in west-central New Mexico.

This report will examine criteria used for site selection and will apply these criteria to the Zuni Mountains. The general geology of this area will be summarized and the work in progress will be discussed. In conclusion, an exploration program for this area will be proposed.

GENERAL CRITERIA FOR DRY HOT ROCK SITE SELECTION

Certain basic criteria for site selection are implicit in the definition of the dry hot rock method of geothermal energy extraction. These, of course, are the requirements that (1) technically usable temperatures can be reached within economic drilling depths, (2) the resource rock is either impermeable or that its permeability can be controlled, and (3) artificial, controlled permeability can be created. Other criteria are suggested by environmental and economic concerns. These would include avoidance of currently active fault zones or faults that could reasonably be expected to be activated by fluid injection. Potential solubility of the resource rock also requires consideration. In general, all effects of massive fluid injection must be considered during site selection.

Economic factors to be considered include proximity to major users of electrical or thermal energy. If electrical energy generation is anticipated, the availibility of a transmission network is obviously important. Also falling within the category of economic considerations is the availability of the necessary volume of water for injection.

When the feasibility of a new method is being tested, it is apparent that the first demonstrations should be made where conditions maximize the possibility of success. With success demonstrated under the most ideal conditions, more difficult cases may be examined and tested and eventually some type of cutoff determined. 
For the dry hot rock method, optimizing the possibility of success means choosing a site where impermeable rocks with usable temperatures (more than $200^{\circ} \mathrm{C}$ ) can be reached with minimum drilling. This implies that areas of abnormally high heat flow should receive first consideration in site selection. As techniques are developed and improved, areas with lower heat-flow values may become suitable targets.

\section{LOCATION AND GEOLOGIC SETTING}

The Zuni Mountains consist of a large, wel1dissected, northwest-trending anticline, the Zuni uplift, within the Colorado Plateau province of westcentra1 New Mexico (Figs. 1 and 2). Although in general, the area is sparsely populated, two population centers, Grants and Gallup, are located on the northern flank of the mountains along Interstate Highway 40. Access to the eastern and southern portions of the mountains is provided by New Mexico Highway 53. On the west side of the mountains access is provided by New Mexico Highway 32 . Unpaved $10 \mathrm{~g}-$ ging and ranch roads provide further access within the mountains. Much of the land encompassed by the mountains is federally owned and is part of the Cibola National Forest.

The Zuni uplift apparently has been a topographic high several times during geologic time. Kelley ${ }^{1}$ believes that lower Paleozoic rocks were deposited throughout the region and that they were subsequently eroded during late-Devonian time.

According to Kelley, ${ }^{1}$ deposition occurred during the Mississippian Period, with uplift and erosion during early-Pennsylvanian time. Subsidence then occurred and deposition continued until the latePermian. Again uplift occurred with resulting erosion. The area remained as a topographic high until the late-Permian. Again uplift occurred with resulting erosion. The area remained as a topographic high until the late-Triassic, when subsidence occurred again. In late-Jurassic time, the Zuni Mountains were uplifted once again and remained positive until the early-Cretaceous when subsidence again took place. This latest period of subsidence was terminated by the Laramide orogeny about 63 million years ago. Kelley ${ }^{1}$ has estimated that at that time the area was covered by 1829 to $3049 \mathrm{~m}$ ( 6000 to $10,000 \mathrm{ft})$ of sediments.
PRECAMBRIAN GEOLOGY OF THE ZUNI MOUNTAINS

During World War II interest in fluorite led the U.S. Geological Survey to map in detail ${ }^{2}$ the center of the Zuni Mountains, where deposits of this mineral are common. Goddard's map shows that in the southeastern portion of the mountains, the Precambrian core of the anticline is exposed over a large area. Two smaller exposures of Precambrian rocks are located to the northwest along the axis of the anticline. These latter two exposures were not mapped by Goddard.

Based on Goddard's work, ${ }^{2}$ a large variety of metaigneous and metasedimentary rocks make up the Precambrian core of the mountains. The most abundant rock type is a pink-to-gray gneissic granite. of lesser but still major importance are metarhyolite and porphyritic aplite. Other rock types are relatively minor in abundance. The Precambrian stratigraphic section is shown in Table $I$.

Most of the Precambrian rocks in the Zuni Mountains are strongly foliated. In general, the foliation strikes northeast to east-northeast and dips steeply (70 to 80 degrees) to the southeast or northwest. Several sets of Precambrian dikes ranging in composition from hornblendite to granite cut the gneisses approximately at right angles to the foliation. Dikes of porphyritic granite generally parallel the strike of foliation. Although these orthogonal dikes have not yet been dated, similar ages would suggest that they developed in a tensional environment, perhaps due to a diaphiric rise.

PALEOZOIC AND MESOZOIC ROCKS OF THE ZUNI MOUNTAINS Paleozoic rocks of the Zuni Mountains include only those deposited during the Pennsylvanian and Permian periods, ${ }^{3}$ older Paleozoic rocks having been removed by erosion. According to Smith, 3 Precambrian rocks are overlain by arkose and conglomerate containing pebbles derived from the Precambrian rocks. Included within the arkose and conglomerate are impure limestone beds containing fossils of pre-Permian age. Permian rocks include, in order of decreasing age, the Abo, Yeso, Glorieta, and San Andres Formations. The Permian section has a total thickness of about $610 \mathrm{~m}(2000 \mathrm{ft}) .^{3}$ Permian-age rocks are we11 exposed where they form cuestas dipping outward from the core of the anticline. 


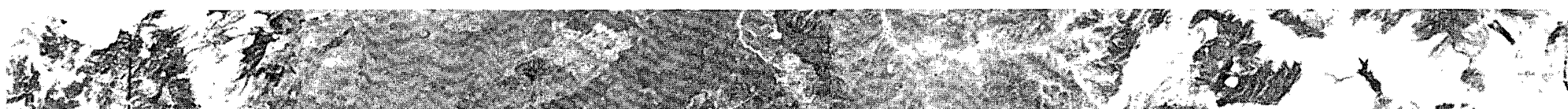
3.

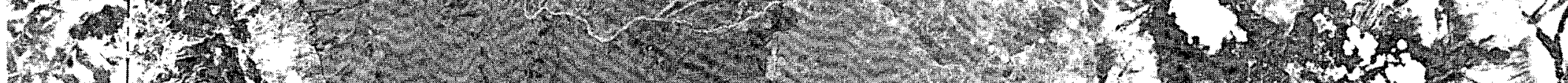

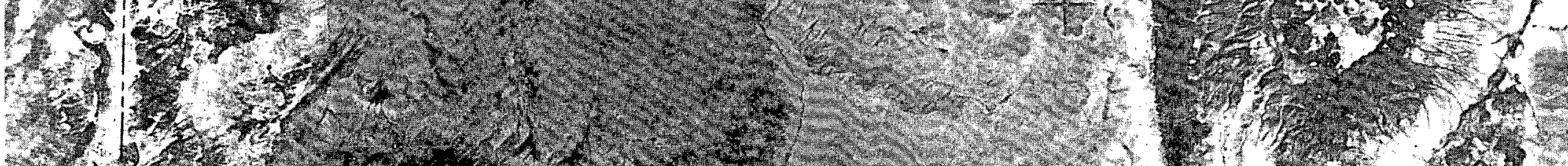

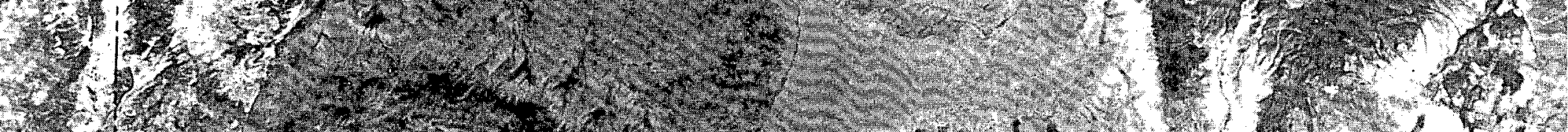

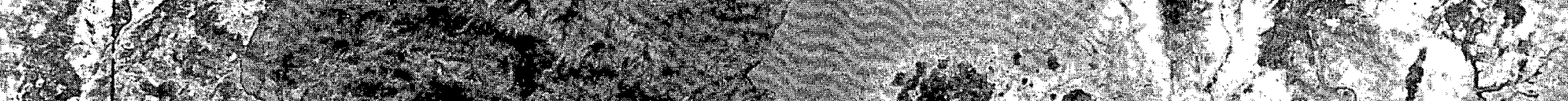

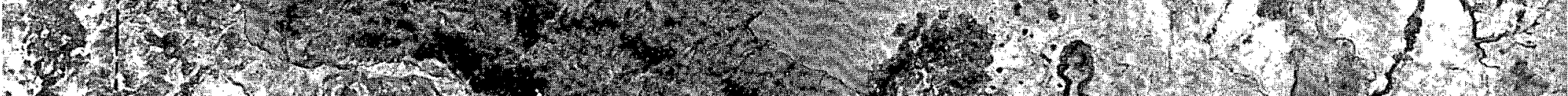
H.

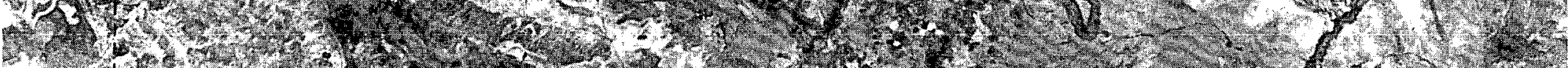

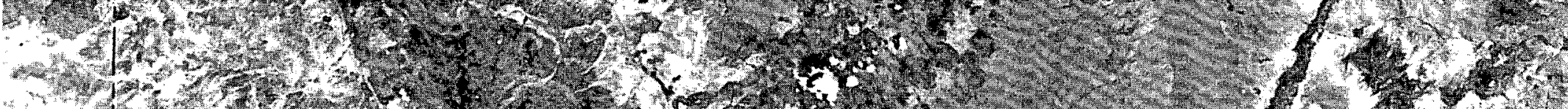
to

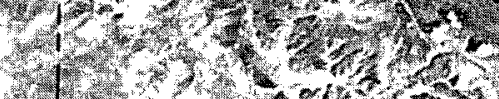

1.

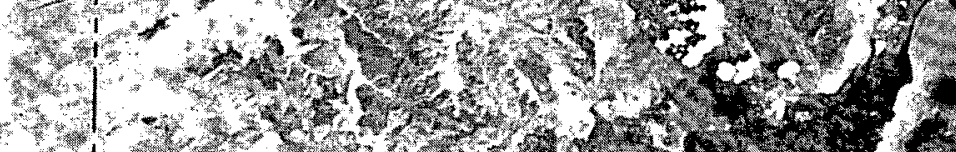

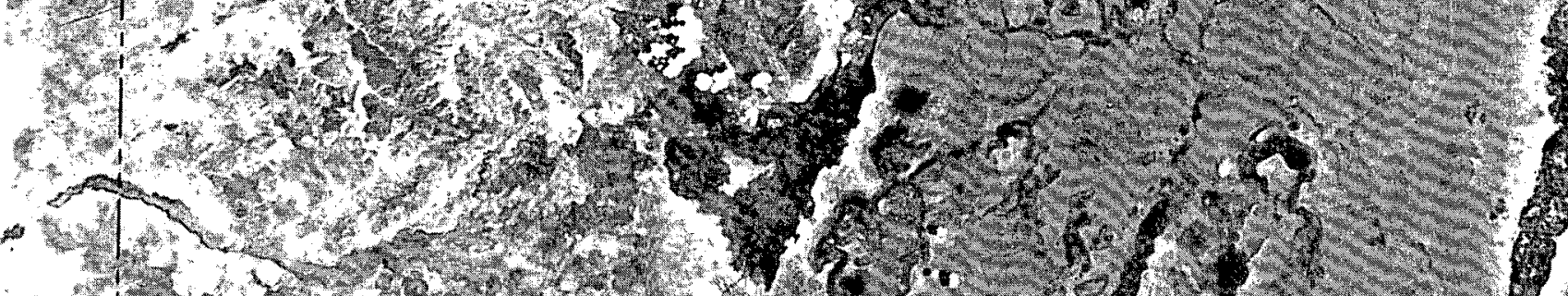
(1) m.

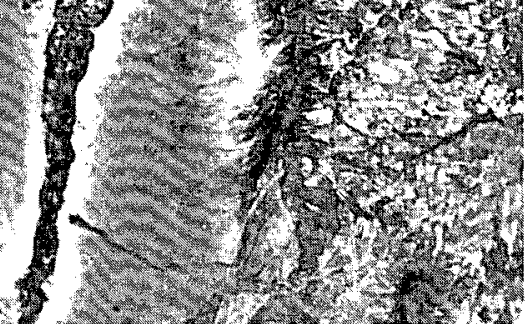

Fig. 1. Composite ERTS photograph of the Zuni Mountains area, western New Mexico. Figures 2 and 3 are vellum overlays of this photograph and are included in the back pocket. 


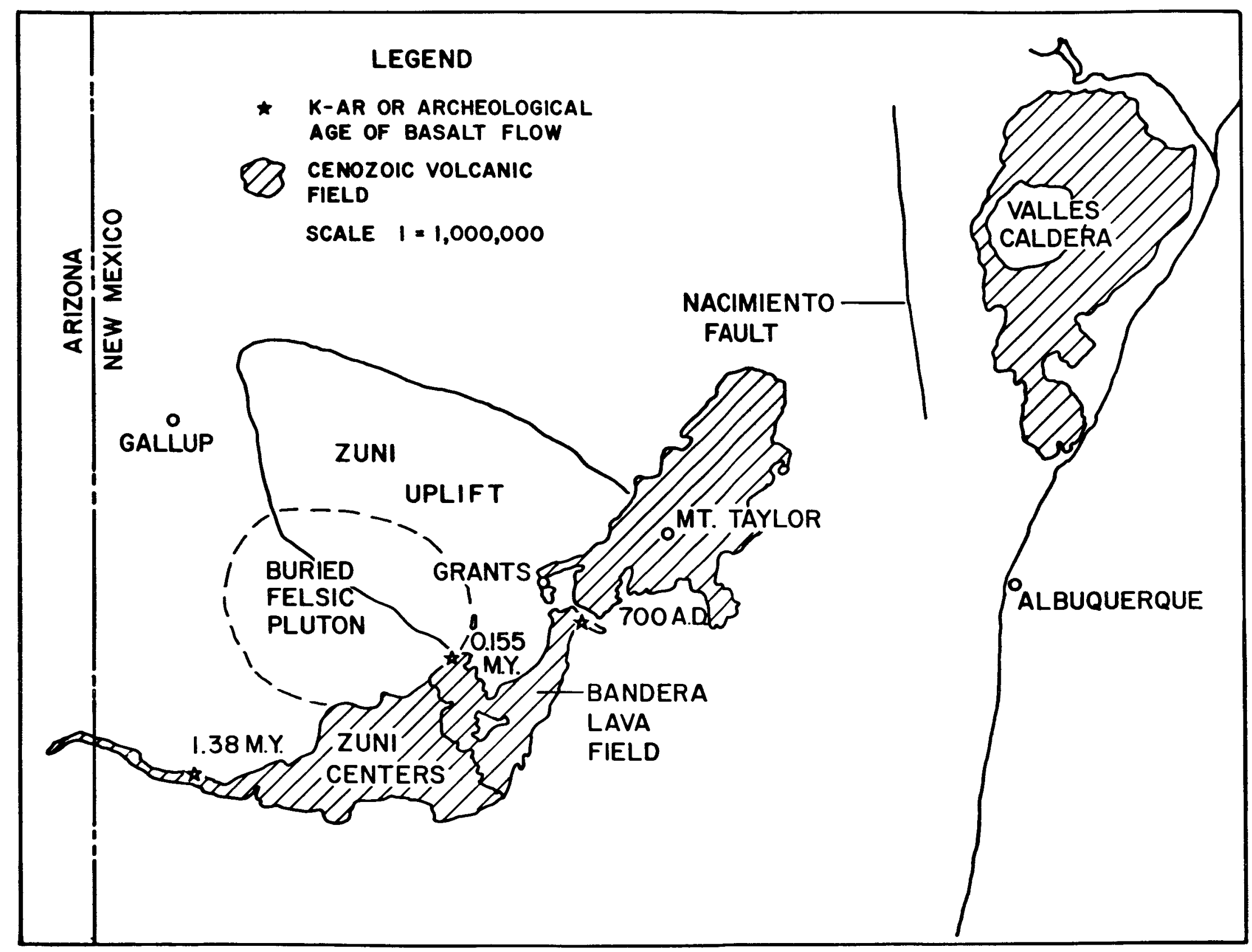

Fig. 2. Index map of features shown on ERTS photograph. 
TABLE I

PRECAMBRIAN ROCKS OF THE ZUNI MOUNTAINS, NEW MEXICO

Inferred

Volumetric

Rock Type

Importance

Remarks

Biotite granite

minor

Syenite

Diorite and monzonite dikes

Hornblendite, gabbro and intrusive basalt

Metarhyolite

very minor

very minor small dikes

very minor sma11 NW

striking dikes

Porphyritic aplite

Gneissic aplite

Porphyritic granite

Aplit ic granite

Gneissic granite

Quartz monzonite

gneiss

Quartzite

Hornblende gneiss

Injection gneiss

Biotite schist major

major

minor

minor

major

major

minor

very minor

minor

minor

minor may be ash flow

stocks and dikes

small dikes

confined to shear zone

Mesozoic rocks are confined to the outer flanks of the uplift outside the area of main interest of this report.

\section{CENOZOIC ROCKS OF THE ZUNI MOUNTAINS}

Cenozoic rocks in the Zuni Mountains apparent1y were emplaced during two discrete periods separated by about 24 million years. By analogy with the timing of other volcanic and intrusive events along the Zuni lineament, the older period activity occurred in the mid-Tertiary. This activity consisted of the emplacement of diabase dikes along the margins of northwest-striking Precambrian dikes and northwest-striking faults or fracture zones. Paralle1 dikes south of the mountains near Quemado have been dated at 27 million years o1d. ${ }^{4}$ To the northwest, diatremes are of approximately the same age. 5,6

The second period occurred in the late-Cenozoic, when basalts were erupted from numerous vents throughout the area. Since these basaltic rocks are regarded as potential heat sources they will be examined in detail in this report.

There are three basaltic volcanic centers within the main mass of the Zuni Mountains. From north to south these are the Cerro Colorado volcano, the

Paxton Springs volcano, and an unnamed volcano which sits astride the Continental Divide on Oso Ridge. For convenience, we will refer to this vent as the Oso Ridge volcano. Numerous other centers occur on the southern and eastern flanks of the mountains where they make up the Bandera lava field and the Zuni volcanic centers. Earth Resource Technological Satellite (ERTS) photographs of this area indicate multiple periods of volcanic activity within these fields. To the north, just outside the mountains, is El Tintero volcano which erupted the Bluewater flow, a tholeiitic basalt. Northeast of Grants is the Mt. Taylor volcanic center. As was discussed by Laughlin et al., ${ }^{7}$ all these centers except Mt. Taylor erupted only basaltic magmas. Mt. Taylor erupted a complete series of magmas ranging from basaltic to rhyolitic in composition. Although the centers within and south of the Zuni Mountains erupted only basaltic magmas, the compositional range was large ${ }^{7-10}$ and alkalic to tholeitic magmas were erupted from centers only a kilometer or so apart. This diversity of composition suggests that a complex plumbing system was operative during the eruptive history of the area. Compositional differences also suggest that different depths within the mantle were tapped during these eruptions. The importance of this will be discussed below.

Volcanism in this region has apparently continued for a period of several million years. In the immediate area, the oldest volcanic features are a series of late-Pliocene (about 3 million years old ${ }^{11}$ basaltic plugs which dot the valley immediately east of Mt. Taylor. These plugs contain ultramafic inclusions indicating that the source for the magma was in the mantle. Slightly later, at 1.38 million years before present, ${ }^{4}$ a large fissure eruption of tholeiitic basalt occurred south of the mountains within the Zuni centers. This material filled the valley before it flowed westward $48 \mathrm{~km}$, crossing the Arizona state line. Within the Bandera lava field on the southern flank of the Zuni Mountains, the surface flow exposed beneath Bandera Crater has an age of 0.188 million years. ${ }^{4}$ The remainder of the centers within this field are considerably younger. On the basis of archeological evidence, the youngest flow in the field, the McCarty flow, was erupted at about 700 A.D. ${ }^{12}$ Thus within this area volcanism continued for about 3 million years, terminating at about $700 \mathrm{~A} . \mathrm{D}$. 
The greatest part of the activity probably consisted of fissure eruptions of tholeiitic basalt, although pyroclastic eruptions of alkali basalt have produced more spectacular features. Actual vents can not be recognized for many of the flows, but the orientation of cinder cone alignments suggest that, for the Zuni centers and Bandera lava field, northeast-striking fractures were the controlling features for the vent locations. ${ }^{7}$ Some of these orientations are so striking that no doubt exists as to the presence of the controlling fracture. (For example, the chain of seven cinder cones southwest of Bandera Crater is obviously aligned along a northeast-striking fracture.)

Within the Zuni Mountains, the Cerro Colorado and Paxton Springs volcanoes are located on northsouth-striking faults which cross the axis of the anticline at an angle of about 45 degrees. The 10calizing feature for the Oso Ridge volcano is unknown at this time.

Strontium isotopic evidence, ${ }^{10}$ and the presence of ultramafic inclusions in the cinders from Bandera Crater, ${ }^{10}$ indicate that this volcano also tapped the mantle.

EVIDENCE OF HIGH GEOTHERMAL GRADIENTS WITHIN THE ZUNI MOUNTAINS

Both direct and indirect evidence exists for the presence of high geothermal gradients within the Zuni Mountains. Direct evidence for the existence of high heat flow in the Zuni Mountains is the anomaly shown on Reiter et a1.'s 13 heat-flow map of New Mexico. Their map shows two linear anomalies within the state, one along the Rio Grande rift and the other a northeast-trending anomaly extending from the Arizona-New Mexico state line to the Zuni Mountains. Most of the Zuni Mountains would be encompassed by this latter anomaly.

Indirect evidence consists of the presence of the three volcanic centers within the main mass of the mountains and numerous centers around the flanks. These centers, active from 3 million years ago up to essentially the present, have acted as long-term heat sources. Structural control of vent locations by faults or fractures suggests that at depth large dikes may be common. Such features would increase the amount of thermal perturbation over that produced by cylindrical conduits. The diversity of chemical compositions of the basalts over short horizontal surface distances would indicate that many distinct linear feeders were operative during the volcanism. This would again increase the amount of thermal perturbation relative to simpler settings with a single feeder. These thermal effects must be added to the regional heat flow of about 1.2 heatflow units (HFU) for the Colorado Plateau.

Additional indirect evidence is provided by an examination of the tectonic setting of the Zuni Mountains. These mountains are aligned in a northwest direction along the Zuni lineament, which extends from the Big Bend region of Texas to the high plateaus of Utah. A second lineament, the Jemez zone or Globe mineral belt, ${ }^{14}$ intersects the Zuni. lineament at the southeast end of the mountains. These lineaments, which originally were defined (mainly by economic geologists) on the basis of several criteria have one feature in common. The criteria used to delineate them are related to thermal perturbations. For example, the Zuni lineament is marked by such diverse features as igneous dikes, volcanic centers, ultramafic inclusion localities, diatremes, and minor lead deposits. The dikes, volcanic centers, inclusion localities, and diatremes are clearly thermally produced features. These features also give some indication of the depths tapped by the lineament. Strontium from basalts in the Zuni Mountains has isotopic ratios typical of mantlederived material. ${ }^{10}$ Ultramafic inclusions from Bandera Crater and from the Rio Puerco sites also indicate that the mantle was the source of the inclusions and their host basalts. ${ }^{10,15}$ The lead deposits have lead isotopic ratios which indicate that the lead was transported from the mantle at two distinct times: ${ }^{16}$ one 1700 million years ago and one during mid-Tertiary time. Transport upward of the lead from the mantle by whatever means is also a thermally driven process. The validity of this younger period of thermal activity is confirmed by midTertiary potassium-argon ages on dikes parallel to the Zuni lineament. 4

The Jeme $z$ zone also has apparently tapped the mantle. Ultramafic inclusion localities have been found southwest of the Zuni Mountains near Globe, Arizona. Hedge ${ }^{17}$ has obtained mantle strontium isotopic ratios on the basalts from this locality. 
We believe that these lineaments represent breaks or zones of weakness in the Precambrian basement rocks which have repeatedly been reopened as the stress fields have changed during geologic time. When these zones are placed in tension, material may move up from the mantle transporting energy as well as mass to or near the surface. Such features are clearly prime candidates for dry hot rock sites.

POSSIBILITY OF A BURIED PLUTON UNDER THE SOUTHWEST FLANK OF THE ZUNI UPLIFT

Geophysical, geological, and ERTS photographic evidence is available that suggests that a large buried felsic pluton is present beneath the southwestern flank of the Zuni uplift.

Throughout the western United States, negative gravity anomalies are found associated with felsic plutons. Within New Mexico such anomalies are coincident with the locations of the Valles Caldera and Mt. Taylor. Both of these volcanoes erupted felsic magmas and some type of buried magma chamber or pluton is certainly present beneath both. The Transcontinental Geophysical Survey Bouguer Gravity Map (USGS Misc. Geol. Invest. Map I-533-13) shows a prominent negative anomaly of about $20 \mathrm{mgal}$ beneath the southwestern flank of the uplift. Although this survey extended only as far south as $35^{\circ} \mathrm{N}$ latitude, so that the contours are open to the south, no doubt in the validity of this low exists. The gravity map of Woollard ${ }^{18}$ also confirms its existence. In magnitude, the anomaly is comparable to those associated with Mt. Taylor and the Valles Caldera. In areal extent, even disregarding the $35^{\circ} \mathrm{N}$ cutoff, it exceeds both of these other anomalies.

Strong support to the presence of a buried pluton is provided by ERTS imagery. The September 26, 1972, multiband image of this area shows an elliptical feature roughly 58 by $43 \mathrm{~km}$, coincident with the gravity anomaly. The major axis of this feature is oriented east-west. Even better resolution of the feature is provided by the black and white ERTS mosaic of the state of New Mexico. A portion of this photo has been reproduced as Fig. 1. Overlays showing geologic interpretation of the area and the Bouguer gravity data are included as Figs. 2 and 3. The southeastern margin of this ellipse is approximately coincident with the northeastern portion of the chain of seven cinder cones extending southwest from Cerro Bandera. The Continental Divide follows the crests of this chain of cones. Proceeding northward, the eastern boundary of the ellipse is marked by the north-south-striking faults along which the Paxton Springs and Cerro Colorado volcanoes are located. A fault separating Precambrian-age from Paleozoic-age rocks forms the northern boundary of the ellipse. The western and southwestern boundaries are delineated by drainage systems.

\section{DRY HOT ROCK POTENTIAL OF THE ZUNI MOUNTAINS}

The initial criterion that must be met by any possible dry hot rock site is that a rock temperature of about $200^{\circ} \mathrm{C}$ can be reached within economic drilling depths. The Zuni Mountains fall within a large region with a heat flow between 2 and $2.5 \mathrm{HFU} .^{14}$ Even without the effects of the possible buried pluton, the regional heat-flow values suggest that sites with the necessary geothermal gradient may be found in or near the zuni Mountains. If the felsic pluton exists, it, like the basaltic volcanoes, would represent only local "hot spots" superimposed on the regional high.

The second criterion is that impermeable rocks are present. Experience from the Fenton Hill Site indicates that, in Precambrian basement rocks, fractures become better sealed with depth. Fracture zones may still exist but long intervals of impermeable rock are available for hydraulic fracturing. The Laramide-age fluorite mineralization found in the Zuni Mountains suggests to us that we may have even better chances of finding impermeable rock in the Zuni Mountains than at Fenton Hill. The solutions which deposited the fluorite moved upward through the Precambrian rocks, depositing this mineral along fractures and shear zones. It is likely that the deposition process sealed available fractures rendering them impermeable. Since fluorite is usually deposited at relatively shallow depths and lower temperatures, we would expect the nature of the fracture fillings to change with depth. These deeper fracture fillings could include sulfide minerals amenable to solution mining during energy extraction.

It should be noted that the Zuni area is one of low seismic activity. This is important from two aspects. The potential for seismic events being induced by the downhole injection of fluid is appreciably less in a tectonically quiet area. Secondly, a 


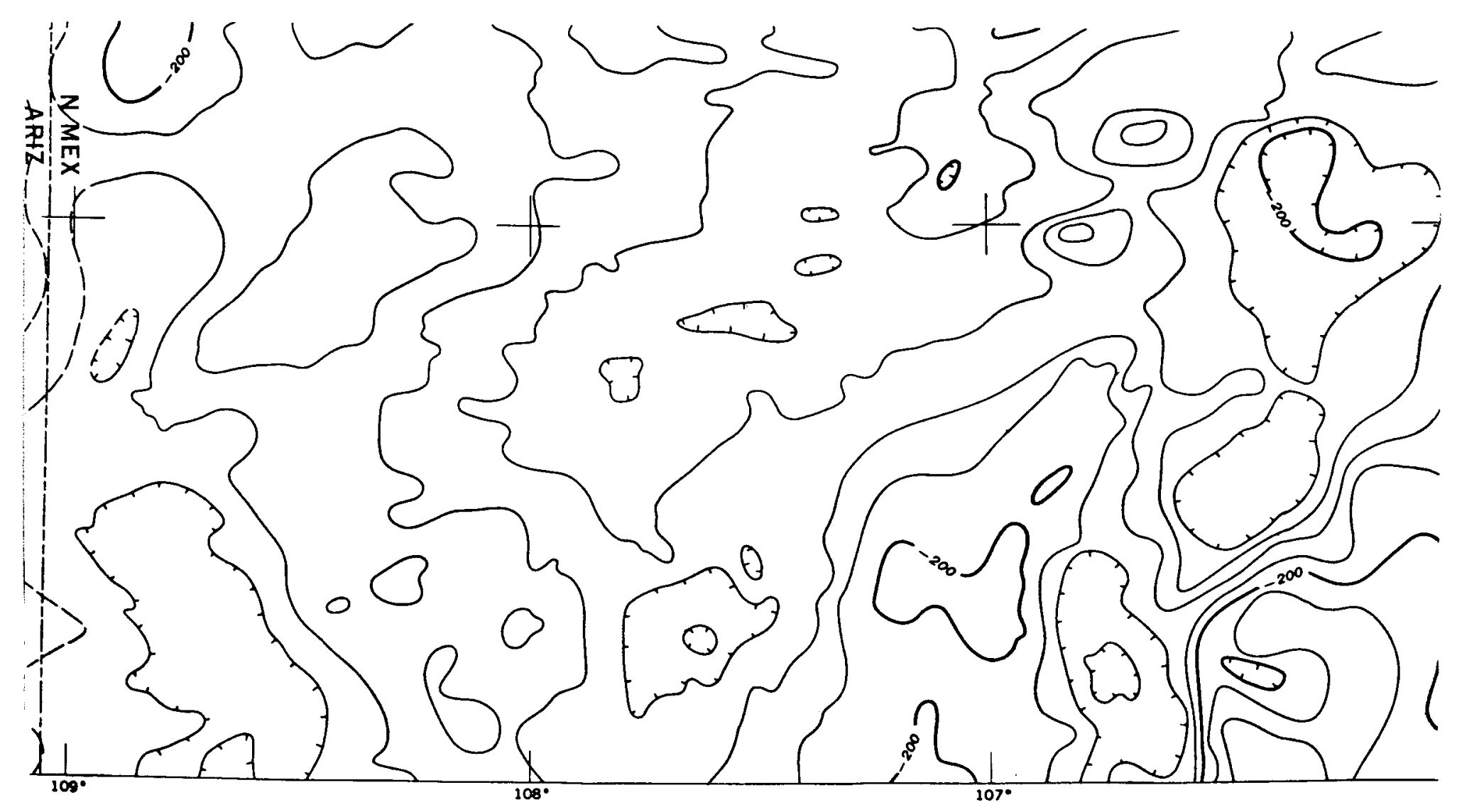

Fig. 3. Bouguer gravity map of northwestern New Mexico. Adapted from U.S.G.S. Map I-533-B. Overlay may be matched to the photograph (Fig. 1) using the Arizona-New Mexico state line and the small cross. 
quiet seismic area provides the environment necessary

for the healing of the natural fractures.

The geographic location of the Zuni Mountains

is such that if either electrical or thermal energy can be produced a ready market is available. The towns of Grants and Gallup are obviously potential consumers of any electrical energy produced. With the presently available transmission network even Albuquerque must be considered a possible consumer. The uranium extraction industry centered at Grants is a large consumer of thermal energy. If production of thermal water could be sited close enough to Grants, this industry should be regarded as a potential consumer.

CURRENT LASL WORK IN THE ZUNI MOUNTAINS AREA

A very modest site-evaluation program has been started in the Zuni Mountains. Some of this work is related to student thesis projects directed by Laughlin while at Kent State University. Our current work is summarized briefly below.

A. Literature Search

Relatively few papers or maps have been published on the geology of the Zuni Mountains. These have been collected and data from them compiled. The USGS topographic maps and aerial photographs have been obtained for areas of major interest.

B. Geologic Investigations

Hand samples have now been collected of all Precambrian rock units shown on Goddard's map. ${ }^{2}$ Specimens were also collected of two mid-Tertiary diabase dikes shown on his map. Thin sections are now being prepared of these samples, and petrographic work will begin shortly. Aerial-photograph interpretation will begin during the fall and winter, 1975-76.

C. Geochemical-Geochronological Investigations Geochemical studies in the Zuni Mountains have been aimed primarily at characterizing the metamorphic and igneous rocks exposed in the core of the mountains. Samples of these units are now being examined to select fresh, unaltered samples for chemical analysis. The results of these analyses will be used both for characterization of the rocks and for comparison with the Precambrian rocks from GT-2. Because of the prior emphasis on the Cenozoic basalts as discussed above, we are concentrating our efforts on the Precambrian and mid-Tertiary rocks.
Although much geochronological work is planned, our work to date has been directed at determining the time of initiation of volcanism. A cooperative program has been started with Paul E. Damon of the University of Arizona to obtain potassium-argon ages on the basalts. Results have been obtained from the first group of samples. Samples of the mid-Tertiary dikes have also been sent to Damon for dating in an attempt to determine the time at which the stress field had this orientation.

D. Geophysical Investigations

Our geophysical work has been limited to the drilling of two shallow heat-flow holes near the Paxton Springs volcano. We hope to complete about six holes in that area and several others to the northwest within the exposed basement rocks.

RECOMMENDED EVALUATION PROGRAM FOR A DRY HOT ROCK DRILL SITE IN THE ZUNI MOUNTAINS

Geothermal evaluations within the Zuni Mountains may be subdivided into three broad types: geological, geochemical-geochronological, and geophysical. A wide variety of techniques can be applied within each of these groupings.

\section{A. Geological Methods}

1. Genera1 geological mapping of Precambrian exposures in the Zuni Mountains. Included herein would be a careful rechecking of the Precambrian exposures mapped by Goddard. ${ }^{2}$ The two other major Precambrian exposures within the Zuni Mountains should also be mapped at the same scale used by Goddard. Cross sections across the axis of the anticline should be prepared showing projected depths to the Precambrian basement where it is covered by younger rocks.

2. Detailed petrographic studies of Precambrian rocks within the Zuni Mountains. Thin sections should be prepared of each of the Precambrian units and standard modal analyses performed on these rocks. If possible this work should be combined with other geological studies to allow prediction of the rock types to be expected at given depths.

\section{Fracture studies. Fracture orientations} and frequencies within the Precambrian rocks should be determined at all possible scales, beginning with microfractures and extending through field measurements and aerial photography to the 1:250,000 scale of ERTS photographs. Rose diagrams should be 
prepared of fracture orientation at each scale and compared to attempt prediction of future hydraulic fracture directions.

4. Foliation and lineation studies. Detailed studies should be made of the orientations of all planar and linear alignments of minerals within the Precambrian rocks. These results should be correlated with the fracture studies to assist in fracturedirection prediction.

\section{Delineation of faults and determination of}

fault movement. Numerous faults are shown on Goddard's map, ${ }^{2}$ but in most cases dips are not shown nor are relative motions on the faults. Because of problems related to induced movement along faults, these features must be carefully mapped. Those areas not mapped by Goddard should be carefully examined for the presence of faults, and relative motion determined. Both ground mapping and photographs should be utilized to locate these features.

6. Mapping of Tertiary dikes. Goddard's map shows several Tertiary-age dikes distributed along the borders of Precambrian dikes. These features should be checked for their presence. These bodies should be studied petrographically and an attempt should be made to relate their orientation to the stress field within the Zuni Mountains.

7. Detailed mapping of fluorite bearing veins. The original purpose of goddard's map was to delineate the location of Laramide-age fluorite veins. These features should be examined in detail because of possible relations to economic mineral deposits recoverable by solution-mining techniques. The orientation of these features may also give some clue as to the orientation of the Laramide stress field.

8. Determination of the existence of a buried felsic pluton beneath the southwestern margin of the Zuni Mountains. Gravimetric data and ERTS imagery suggest that a large $58-\mathrm{km}$ by $43-\mathrm{km}$ felsic pluton lies buried beneath the southwestern flank of the Zuni uplift. The gravity anomaly in this area is comparable to those exhibited by the late-Cenozoicera Mt. Taylor volcano and Jemez Caldera. If the existence of such a buried pluton can be demonstrated, then a very significant heat source is present within the area. This additional heat source superimposed on what is already believed to be a thermal anomaly greatly increases the potential of the Zuni Mountains as a dry hot rock drill site. Geologic evidence should be sought to test this possibility. In particular, geomorphological evidence obtained from both airborne and satellite imagery and from normal ground mapping should serve as a test for the theory. If the pluton is only shallowly buried, evidence for its existence may be provided by hydrothermal alteration of the overlying rocks. Geochemical and geophysical tests will be discussed below.

B. Geochemical-Geochronological Methods

1. Major- and trace-element chemistry of Precambrian rocks. All Precambrian rock units should be chemically characterized with respect to both major and trace elements. These data are necessary for both classification purposes and to anticipate problems related to solution if a two-hole energy extraction system is eventually established.

2. Major- and trace-element chemistry of Cenozoic dikes and flows. Because a large hydraulic fracture could intersect some of the numerous Tertiary dikes or feeders of the late-Cenozoic basaltic flows, these rocks should be chemically characterized. Dellechaie ${ }^{9}$ has completed a thorough study of the chemistry of the basaltic flows. Most of this effort should therefore be spent on the midTertiary dikes.

3. Major- and trace-element chemistry of fluorite deposits. The presence of large vein-type fluorite deposits within the Zuni Mountains suggests that other mineralization types may also be present. Detailed chemical studies should be performed on these fluorite deposits to determine if any metals may be recovered from them as by-products of energy extraction.

4. Radiometric dating of Precambrian rocks, Tertiary dikes, fluorite deposits, and late-Cenozoic flows. For several reasons radiometric dating should be performed on the above units. Dating of Precambrian units will allow correlation with other Precambrian rocks from New Mexico, Arizona, and Colorado. This information in itself is of considerable value to the geologic community. Since there are several Precambrian dikes present within the Zuni Mountains, dating of these rocks will allow determination of the orientation of the stress field at specific points in geologic time. For the same reason the Tertiary dikes and the fluorite veins should also be dated. The late-Cenozoic basaltic flows with their feeders are one of the heat sources 
which may contribute to the geothermal anomaly within this area. Although some of these flows are too young to be dated by the potassium-argon method, where possible the older flows should be dated to provide information on the duration of the thermal perturbation.

\section{Time-temperature profiles across dikes and}

wall rocks. Potassium-argon and $\mathrm{f}$ ission-track dating should be used to construct time-temperature profiles across these igneous rocks and the wall rocks they intrude. This information will permit evaluation of the scale of the thermal perturbations. (This work will be done in collaboration with Dr. Robert Forbes of the University of Alaska and Dr. Charles Naeser of the U. S. Geological Survey.)

C. Geophysica1 Methods

Considerable literature exists on the relationship of various geophysical parameters and the thermal enhancement of a number of areas. Refinement of this relationship will allow a more organized and efficient evaluation of a particular geothermal potential.

1. Gravity studies. Correlations have been made between high terrestrial heat flow and negative Bouguer gravity anomalies. ${ }^{19,20}$ High values of heat flow can often be attributed to the emplacement at depth of low-density silicic rocks which have a re1atively high thermal conductivity and thermal generation due to a high content of natural radioactive elements. ${ }^{21}$ The trends observed in the gravity maps suggest that geologic features such as the Zuni Mountains and the Valles Caldera are related at depth.

The existing gravity maps, which are based on a regional-scaled station spacing, would be detailed in areas of particular interest for a delineation of the suspected relationship. The maps would be subjected to computer analysis for second-derivative residuals and harmonic components.

2. Geomagnetic studies. High terrestrial heat flow and low electrical resistivity in the deep crust or mantle have been correlated with upwelling of the $1000^{\circ} \mathrm{C}$ isotherm. ${ }^{22-35}$ Maps of the crustal electric conductivity can be drawn by measuring the natural transients of the electromagnetic and electric fields. The reaction of a station to events with periods ranging from minutes to several hours allows investigations from a few hundred meters to several hundred kilometers in depth. The ability for studies at great depth allows one to map the configuration of the $1000^{\circ} \mathrm{C}$ isotherm, the temperature at which several physical properties of rock began to change. Ridges or upwelling in the $1000^{\circ} \mathrm{C}$ isotherm will be reflected in elevated values of heat flow at the surface. The use of transients with various frequencies gives a map which can be interpreted as a contour map of relative temperatures from depth to near surface.

The relationship of the Zuni area to thermal enhancement will be investigated by the use of geomagnetic depth-sounding techniques in conjunction with magnetotelluric stations at locations anticipated for geologic reasons to be critical in the overall interpretation.

3. Heat-flow measurements. The program for heat-flow measurements will proceed in two stages. Locations of the first set of heat-flow stations will be based on fundamental geologic considerations. The current level of knowledge of the area will allow a mapping of many of the major heat-flow features. The second set of stations will be located to test the results of the geomagnetic studies, especially to check the existence of any thermal ridges or trends mapped.

4. Detailed site investigations. Once a particular local area is selected, based on large area studies, detailed geophysical site investigations will be necessary.

a. Microseismic-earthquake activity of the area will be monitored for a period of several months to detect any current tectonic activity or "noise" that is normally associated with active hydrothermal systems. 36

b. Seismic-reflection surveys will be utilized to delineate the geologic subsurface structure --especially faults. The spatial distribution of faults will give some insight into the geologic history and in particular the tectonic history of the area. Knowledge of the tectonic history will aid in predicting the orientations of induced fractures.

c. Electrical-resistivity surveys. The area of the site will be surveyed by measuring the resistivity as a function of depth, utilizing controlled surface energy sources. ${ }^{37}$ The survey will provide a further evaluation of the possible existence of an active hydrothermal system. To some extent 
inferences can also be made as to the decrease of open or unhealed fractures with depth by assuming that the major increase of resistivity with depth will reflect a decrease in water content rather than a change in rock type.

\section{REFERENCES}

1. V. C. Kelley, "Tectonics of the Zuni-Defiance Region, New Mexico and Arizona," New Mexico Geological Society Eighteenth Field Conference Guidebook, 28 (1967).

2. E. N. Goddard, "Geologic Map and Sections of the Zuni Mountains Fluorspar District, Valencia County, New Mexico," U.S.G.S. Misc. Geol. Inv. Map I-454 (1966).

3. C. T. Smith, "Geology of the Zuni Mountains, Valencia and McKinley Counties, New Mexico," in Four Corners Geological Society Guidebook, 53 (1957).

4. A. W. Laughlin and P. E. Damon, Los Alamos Scientific Laboratory unpublished data, 1975.

5. R. L. Armstrong, "K-Ar dating of laccolithic centers of the Colorado Plateau and vicinity," Geol. Soc. Amer. Bull. 80, 2081 (1969).

6. C. W. Naeser, "Geochronology of the NavajoHopi diatremes, Four Corners area," J. Geophy . Res. 76, 4978 (1971).

7. A. W. Laughlin, D. G. Brookins, and J. D. Causey, "Late Cenozoic basalts from the Bandera lava field, Valencia County, New Mexico," Geol. Soc. Amer. Bull. 83, 1543 (1972).

8. J. R. Carden and A. W. Laughlin, "Petrochemical variations within the McCarty's basalt flow, Valencia County, New Mexico," Geo1. Soc. Amer. Bu11. 85, 1479 (1974).

9. F. Dellechaie, "Chemical and petrographic variations in the Cerro Colorado Paxton Springs basalt flows, Valencia County, New Mexico," Unpub. M.S. thesis, Kent State Univ., 1973, p. 54 .

10. A. W. Laughlin, D. G. Brookins, A. M. Kudo, and J. D. Causey, "Chemical and Strontium isotopic investigations of ultramafic inclusions and basalt, Bandera Crater, New Mexico," Geochem. Cosmochem. Acta 35, 107 (1971).

11. W. A. Bassett, O. A. Schaeffer, and R. W. Stoenner, "Potassium-argon ages of volcanic rocks near Grants, New Mexico," Geol. Soc. Amer. Bull. 74, 221 (1963).

12. R. L. Nichols, "McCarty's basalt flow, Valencia County, New Mexico," Geol. Soc. Amer. Bul1. 57, 1049 (1946).

13. M. Reiter, C. L. Edwards, H. Hartman, and C. Weidman," Terrestrial heat flow along the Rio Grande rift, New Mexico and southern Colorado," Geol. Soc. Amer. Bul1. 86, 811 (1975).
14. E. B. Mayo, "Lineament tectonics and some ore districts of the southwest," Trans. AIME, 1958 , p. 1169.

15. A. M. Kudo, D. G. Brookins, and A. W. Laughlin, "Sr isotopic disequilibrium in therzolites from the Puerco necks, New Mexico," Earth Planetary Sci. Letters 15, 291 (1972).

16. W. F. Slawson and C. F. Austin, "A lead isotope study defines a geological structure," Econ. Geol. 57, 21 (1962).

17. C. E. Hedge, Los Alamos Scientific Laboratory, Personal communication.

18. G. P. Woollard and H. R. Joesting, "A Bouguer Gravity Anomaly Map of the United States," U.S. Geol. Surv. Spec. Map, 1964.

19. C. L. V. Aiken and J. S. Sumner, "Implications of Regional Geophysical Patterns in Arizona," EOS Trans. Am. Geophy. Union 56, 349 (1975).

20. E. R. Decker and S. B. Smithson, "Heat Flow and Gravity Interpretation Across the Rio Grande Rift in Southern New Mexico and West Texas," J. Geophy. Res. 80, 2542-2552 (1975).

21. F. G. West, "Regiona1 Geology and Geophysics of the Jemez Mountains," Los Alamos Scientific Laboratory report LA-5362-MS (1973).

22. U. Schmucker, "Anomalies of Geomagnetic Variations in the Southwestern United States," Bu11. Scripps Inst. of Oceanography 13, 165 (1970).

23. J. S. Reitze1, D. I. Gough, H. Porath, and c. W. Anderson, "Geomagnetic Depth Sounding and Upper Mantle Structure in the Western United States," Geophys. J. R. Astr. Soc. 19, 213-235 (1970).

24. M. J. Berry, W. R. Jacoby, W. R. Niblett, and R. A. Stacey, "A Review of Geophysical Studies in the Canadian Cordillera," Canadian J. Earth Sc. $\underline{8}, 788-800$ (1971).

25. R. E. W. Warren, J. G. Sclater, V. V. Vacquier, and R. F. Roy, "A Comparison of Terrestrial Heat Flow and Transient Geomagnetic Fluctuations in the Southwestern United States," Geophys. 34, 463-478 (1969).

26. S. Uyeda and T. Rikitake, "Electrical Conductivity Anomaly and Terrestrial Heat Flow," J. Geomag. and Geoelec. 22, 75-90 (1970).

27. B. Conner, W. H. Cannon, and C. E. Livingstone, "Geomagnetic Depth Sounding and Upper Mantle Structure in the Cordillera Region of Western North America," J. Geophys. Res. 72, 6335-6351 (1967).

28. T. Madden, "Geoelectric Upper Mantle Anomalies in the United States," J. Geomag. and Geoelect. 22, 91-95 (1970). 
29. J. F. Hermance and L. R. Grillot, "Correlation of Magnetotelluric, Seismic, and Temperature Data from Southwest Iceland," J. Geophy. Res. 75, 6582-6591 (1970).

30. P. A. Camfield, D. E. Gough, and H. Porath, "Magnetometer Array Studies in the Northwestern United States and Southwestern Canada,"

Geophys. J. R. Astr. Soc. 22, 201-221 (1970).

31. H. Porath, "Magnetic Variation Anomalies and Seismic Low-Velocity Zone in the Western United States," J. Geophy. Res. 76, 2643-2648 (1971).

32. F. X. Bostick and H. W. Smith, "Investigation of Large-Scale Inhomogeneities in the Earth by the Magnetotelluric Method," Proc. Institute of Radio Engineers 50, 2339-2346 (1962).

33. C. M. Swift, "The Magnetotelluric Method: LowFrequency Field Examples, Arizona and New Mexico," Symp. on Applications of Natural Electricomagnetic Fields in Petroleum and Mining Exploration, Berkeley, CA, March 19-23, 1968, Paper E.2, pp. 2.1-2.28.
34. L. L. Vanyan, V. V. Borets, A. M. Lyapisher, B. Ye Marderfeld, and A. V. Rodionob," Deep Electromagnetic Investigations in the Soviet Far East," Modern Geo1. 5, 65-73 (1975).

35. M. C. Frazer, "Geomagnetic Deep Sounding with Arrays of Magnetometers," Rev. Geophys. and Space Phy. 12, 401-420 (1974).

36. P. L. Ward, "Microearthquakes: Prospecting Tool and Possible Hazard in the Development of Geothermal Resources," Geothermics 1, 3-12 (1972).

37. T. Meiday, "Application of Electrical Resistivity and Gravimetry in Deep Geothermal Exploration," Geothermics Sp. Is. 2 , 303-310 (1970). 